Journal of Education and Vocational Research

Vol. 2, No. 5, pp. 183-196, Nov 2011 (ISSN 2221-2590)

\title{
Issues and Solution of Ethical Climate and Turnover Intention in PTCL
}

\author{
*Sayed Fayaz Ahmed, Zahid Mehmood Awan, Muhammad Khalil Shahid \\ Institute of Communication Technologies, NWFP University of Engineering \& Technology, Peshawar, Pakistan \\ *fayaz_sayer@yahoo.com
}

\begin{abstract}
This study makes significant payment to our beliefs about issues and solution of ethical climate and turnover intention. This research is not only discusses how ethical climate creates trust in supervisor, emotional exhaustion, and organizational commitment but also explains how these parameters affect job satisfaction, which relates to turnover intention. All the parameter, we use in our research is well tested and exercised. To explain our point of view in well understandable manner, a structured model is derived from the literature on the subject. More over this research brings the issue of ethical climate to the discussion table and provides a well-established path to other researchers. The research will make the managers able to lessen the turnover intention in the organization. As the study linking various variables and theories, it suggests the main affects and causes of their interdependences. It also helps managers to maintain such an ethical climate, which leads to job satisfaction and less turnover rate.
\end{abstract}

Key words: Ethical Climate, Turnover Intention, Organizational Commitment

\section{Introduction}

Ethical Climate means organizations the routine behaviors in which it operates as well as the expected events, which are supported, rewarded (Schneider and Rentsch, 1988). As a fact that an organization consists of different types of authorities, teams and history of employment, the perceptions about the climate of organization varies from individual to individual inside the firm walls (Victor and Cullen 1988). In addition to this, a company, organization, sub unit and team may also consist of different climate types such as an ethical climate (Schneider, 1975). Now a day's any organizations contain climates, run from very ethical to very unethical anywhere. One survey of four thousand employees of business responded as, $25 \%$ believed that, in order to meet business objectives ethical conduct was ignored by their company, and some what $17 \%$ believed that misconduct was encouraged by the company to achieve its business objectives (Goodell, 1994). This evidence shows the existence of unethical climate but also tells that the climates of all organizations are not necessary to be unethical. An organization's ethical climate shows the ethical values and expected behavior and how to pressurize the members of the firm (Wimbush and Shepard, 1994; Verbeke et al, 1996). Some hardly recommended that ethical climate should be integrated into the firms (Robin and Reidenbach, 1987) Creating an ethical environment in organization may offer one way for it. On the other hand, its relationship to some job-related result is also unknown, predominantly in business.

Ethical Climate is a hot discussion topic for its relating to many business disgraces. Ethics affect organization in many ways. Primary, clients will go away from the products and services of those organizations with unethical environment (Gilbert, 2003; Babin, 2004). Secondly, some such practices are illegal, and consequently cause the firm's legal responsibility, economic risk, and expenses (Chan, 2002; Neese et al, 2005). Third, unethical environment effect employees through greater workplace stress, decreasing job satisfaction (JS), also decreases job performance, and finally tends to turnover (Babin 2000; Schwepker, 2001; Weeks and Nantel, 2004). An employee's view regarding to the values and norms, trails and other practices of an organization under the candle of Ethics is called Ethical Climate (EC) (Schwepker, 2001). There are three separate details have been suggested by the previous researchers. These researches explain the relationship of ethical climate and Intent to turn over. First is attitudinal theory propose that the evaluation of an object through an individual direct to such attitudes which explains intentions of behavior (Ajzen, 2001). Therefore, if the ethical climate of an organization evaluated positively, will result in greater Job Satisfaction and lower Turnover Intentions (Schwepker, 2001; Mulki et al, 2006). Next, researchers have 
also observed that the leadership also plays a significant function in the Ethical climate and Turnover Intentions relationship (Grojean et al, 2004; Wimbush and Shepard, 1994, Mulki 2006). Statement also shows that those workers who work in an Ethical Climate will trust their supervisor more likely than those who work in unethical climate. In addition, they will be much happier with their duties, and they are less likely to leave their jobs. In conclusion, an Ethical Climate gives cues to the people about their behaviors that are proper in the respective firm, thus it will reduce role stress (Schwepker and Hartline, 2005). A research study also has shown that the Ethical Climate and Turnover Intentions relationship is reconciled by Role Stress and Job Satisfaction (Jaramillo et al, 2006).

There is also a significant relationship between firm's ethical values and its organizational commitments measured by ethical climate and job outcomes relating research. (Hunt et. al, 1989) role difference (Schwepker, 1997), work or job satisfaction (Deshpande, 1996), intention to turnover (Sims and Kroeck, 1994), as well as performance (Weeks and Nantel, 1992). Looking these studies deeply indicates the relation ship between Performance, job satisfaction and ethical values of the organization. Furthermore, the paper (Weeks and Nantel, 1992) checked up the function among job satisfaction and ethical climate in only one department of an organization. Researches showed that Ethical climate and Trust in supervisor Relationship, also made clear through the intervention of Role Stress (Jaramilloet al, 2006a), trust in supervisor (Mulki et al, 2006), and Job Satisfaction (Schwepker, 2001). This research is trying to make understand the basics of ethics and ethical climate in an organization. Today's environments of organizations or firms are a mixture of people having different color and customs, having different codes of conduct, having different culture and dresses etc. These elements make very complex situations for managers, because they don't know what is correct to the other and what not. Some time employees feel emotional exhausted to their managers or fellow worker because they did some thing really harmful to them which they don't take so serious, this phenomenon always leads to decrease the trust on supervisor of fellow worker or make the employees emotionally exhausted. In addition, most of the organization are increasing there profit through down sizing etc, which increase the negative perception about the organization and decrease its values in the market. Some managers fires or punish employees in response to little mistake, which again leads to the leaking of some important information or lessen the organizational commitment.

Organizational climate has great impact on the employees and over all objectives of the Organization. An Unethical climate leads towards "Workplace stress, Job Dissatisfaction, Hurt the Firm's Values and Increases its liability". Therefore, it is necessary to do research on Ethical Climate in PTCL and find out variables leading to turnover intentions. There are many researches about ethical climate in most of organizations. However, further study is required to explore how Ethical Climate leads to Trust in Supervisor, Emotional Exhaustion, Organizational commitment. Most of the Models regarding this topic are very complex and difficult to understand. A need is feeling to create an understandable way and model for describing, how these parameters affect Job Satisfaction, which clarifies a path to Turnover Intention in a single Model. PTCL is always in transition, developing new technologies, hiring and firing employees and having a complex climate and culture. It is felt necessary to find out the reasons of the problems arising from ethical climate and its affects. There are also several problems, creating from the job satisfaction in PTCL, so we felt a need to find out the causes, which make dissatisfaction of jobs.

This study focuses on digging deep into the main causes of turnover intentions in PTCL. In addition, it will get us introduce to the main problems arises from the ethical climate in PTCL which leads employees to quit their jobs. The study will not only enable us to have insight into the causes of turnover intentions but will also provide us help in finding the solutions to these problems. This research will also suggest ways to overcome the problems and improve the current practices, which helps to increase the health of the ethical climate in PTCL. The main objectives of the study are:

- To find out the role of ethical climate in job satisfaction.

- To find out how the employees will be kept committed to their organization.

- To find out how to reduce turn over intentions in Employees.

- To propose a new Model, regarding Ethical Climate and Turnover Intentions in PTCL. 
- $\quad$ To present with the best possible solution for the problematic areas.

\section{Literature Review}

Ethical climate: Ethical climate is the perceptions of firm's practices and experiences having ethical content (Vector and Cullen, 1988). It is also suggested by the literature that there is present an unethical environment in an organization when there is no enforcement of ethical codes and polices and such directives that regularly discourages and correct the unethical behavior (Ferrell and Gresham, 1985). Ethical policy plays a vital part in making ethical decisions in organizational workers (Ethics in American Business, 1998). Ethical behavior with high levels is observed in those organizations where there is existence of ethical policy in action (Ferrell and Skinner, 1988). The decision-making under ethics is greatly affected by the workers when they have enough ethical knowledge about there work and work place (Hegarty and Sims, 1979). Also, when codes are communicated effectively, causes ethical full behavior (Weeks and Nantel, 1992). Behaviors are also affected through rewards and punishment of Supervisors (Trevino, 1986; Posner and Schmidt, 1987).

The above literature clarifies that by implementing ethical codes organization can achieve ethical behaviors. Also if there is a climate of rewarding of ethical behavior and punishing of unethical behaviors, an organization can found a climate of ethics that will influence the ethical behavior of the over all organizations positively. Every organization needs to make an ethical policy and defines clear codes of conduct for it work place. Based on the above study it is also concluded that through effective Ethical climate is necessary to make attitudes and behaviors of employees more positive. In addition, it is a general fact that when employees are working in an environment, run because of equity they will be more loyal to the organization and there will be a positive perception about the organization in their hearts. The following lines are clarifying the main effects of ethical climate and some important variables.

Ethical climate and Trust in Supervisor: Every organization consists of workers and their senior workers, sometime called supervisor. Both of them play a vital role in the working environment for the betterment and performance of the organization. Trust in supervisor means the optimistic outcome which happens when a worker think that he has a fair link with a sincere supervisor (Dirks and Ferrin, 2002). It is the supervisor, who teaches the employees all about the organization and their work. Most of the time employees works under their supervisor and their future are concerned with them. One study says, Boss speak the firm's ethical outlook to employees, provide them beliefs that firms and the supervisor have good values and are fair with them (Ruppel and Harrington, 2000). Ethical climate is the only possible way to improve the trust on supervisor in the hearts of employees. When workers see that the organization's climate is ethical, they feel heroic and healthier to trust their bosses (Strutton, 1993). Therefore, an ethical environment result in trust in supervisor and are supported by one more study that provides empirical positive relationship (Mulki et al, 2006). The literature shows that when there is ethics in an organization's climate, there will be more trust of employees on their bosses. We also draw the relationship as:

\section{H1: Ethical Environment also affects Trust in Supervisor positively.}

Ethical climate and organizational commitment: The interest of an employee in an organization is called organizational commitment. Studies have defined organizational commitment as the combination of attitude and behavior. When an employee identifies with a particular firm and sees that his own goals are similar to that of the organization, he tries to continue his employment in that organization in order to achieve that goals, this type of Organizational commitment is as an attitude (March and Simon, 1958). When there is such a state, in which the employee does with out any other alternate action and select himself to link with the organization. This type of organizational commitment is a behavior (Staw and Salancik, 1977). The psychological bond between the employees and the organization to do something in such a behavior those are reliable with the importance of the organization (Porter, 1974, McDonald, 1999). High organizational commitment has positive effect on both the firms and the individual and a low-level commitment have a negative effect on both of them (Mathieu and Zajac, 1990). Hence, if supervisors wish to influence the organizational commitment positively. One research on female employees results that commitment to the 
organization increase when preferred ethical climate and actual ethical climate of works match (Sims and Kroeck, 1994). In short, it is suggested that in those organization where the workers knows that the organization's climate is more ethical, they will be more committed to it. Making the above literature our base, we can guess that:

\section{H2: Ethical Climate has positive relationship with Organizational Commitment.}

Ethical climate and Emotional Exhaustion: Now a day, a single organization does and offers a plenty of work and services and tries to fulfill more and more demands from the markets. Unnecessary demands from workers causes an emotion of exhausted energy is known as Emotional Exhaustion (Jakson, 1987). As there is the main issue of emotional exhaustion in the today employees, so there are many reasons for it also. The two main basis of emotional exhaustion is Role ambiguity and conflict (Netemeyer et al, 2004). This theory was driven from one of the important theory about emotional exhaustion, which divides it into these main parts. When workers are supposed to do contrary demands causes Role conflict (Rizzo, house and Lirtzman, 1970) and confusion about the actual job responsibility causes Role ambiguity (Rizzo, house and Lirtzman, 1970). When employees are demanded with a high job and having lesser choice freedom experiences emotional exhaustion. These factors create negative perception about the organization, and so the employees of such organizations are dissatisfied. Sometime the organization pays less and demands more or some supervisor or some other bosses may do their work by the employees, which also play as the basis for emotional exhaustion. Making the above literature as our base, we assume that:

\section{H3: Ethical Climate has positive relationship with Emotional Exhaustion.}

Emotional Exhaustion and Job Satisfaction: Emotional exhaustion is defined as the tired mood comes from too much emotional or psychological demand from employees (Jackson, 1987). There are two main sources of psychological tension, the first one is role conflict and the second is role ambiguity (Low et. Al, 2001; Netemeyer, 2004). Role conflict is defined as a situation in which employees are subjected to do mismatched work to their job. Usually, the employees do not perform them as good as they do their actual job (Rizzo, House, and Lirtzman, 1970). There is a strong positive relationship between role conflict and emotional exhaustion (Jackson, 1987). Where the role ambiguity is arises from the misunderstanding and uncertainty about the actual responsibilities of the original job (Rizzo, 1970) which result employees feel flooded. In other words, employees experience emotional exhausted when they face a difficulty in recognizing their correct job responsibilities (Jaramillo et al, 2006b).

No employees in an organization are same. Every employee has different type of attitude and behavior. The attitude reflecting to the likeness and dislikeness of jobs is called Job Satisfaction (Spector, 1985). Their feelings and attitudes do not allow them to smile and make other smile but always live in pessimistic approach for themselves and others. Workers having exhausted emotions often see their self is helpless (Cordes and Dougherty, 1993). This creates and makes them nervous regarding going to job and generate a sense of dissatisfaction about their helplessness to show eagerness for their work (Babakus et al, 1999). When employees are dissatisfied from their job and feel emotionally exhausted do not care for the future of the organization and their jobs. Therefore, emotionally tired workers build up pessimistic approach about customers, the firm, their jobs (Cordes and Doughtry, 1993). The discussion suggests that employees will be happy and satisfied with their jobs if they work in a healthy ethical climate. They will look for the luck of themselves, firm, and customers. This literature also carries me to draw the following assumption.

\section{H4: Emotional Exhaustion has negative relation ship with Job Satisfaction.}

Trust in Supervisor and Job Satisfaction: Every organization contains staff from front line employees to the CEO. Every employee in any organization is working under his/her boss at each level. The employee who is working under other employee is actually working under his/her supervisor. Due to many cases, many researchers are doing researches on bad behavior of supervisor in organizations (Griffin \& O'Leary-Kelly, 2004). One of the reasons of this increased attention to this area is increase in the frequency of such cases in most of the organizations (Griffin \& Lopez, 2005) and its huge impact on the output of the employees and the 
organizations. It is made clear by the researches that these behaviors of bosses have negative effects (Duffy, Ganster, \& Pagon, 2002). Usually some supervisors shows destructive behavior on low level as researches starts on this level initially (Tepper, Duffy, Henle, \& Lambert, 2006), and expanded to the senior and managerial level latterly (Tepper, 2000; Zellars, Tepper, \& Duffy, 2002).

Researchers prove that when there is trust of employees on their supervisor, they will be more loyal to the firm and will be satisfied from their jobs (Mulki et al, 2006). Employees come to the organization for its name and leave it for their bosses. When employees trust their supervisor, they are more satisfied in the organization and so loyal also. There is negative link between Trust in Supervisor and Intent to turn over, which is also, supported studies (Brashear et. al, 2003; Dirks and Ferrin, 2002). The above study clarifies the importance of trust and behavior of supervisors or seniors in the organizations. Senior's trust will ensure employees for their hard work reward and values, which will lead to lessen turnover rate and increases the over all outcomes of the organization. Here in this research, because of the above discussion we can state that there is positive relationship between Trust in Supervisor and Job Satisfaction.

\section{H5: Trust in Supervisor has also positive effect over Job Satisfaction.}

Organizational Commitment and Job Satisfaction: As there are, many jobs and organizations in the market, so there are many theories and researches about them. The type of organizations varies from private sector to public sector and vice versa. Because of different types of jobs, the results are mixed about organizational commitment and job satisfaction. However, it is stronger according to its supporting materials that there is a positive relationship between organizational commitment and job satisfaction (Johnston et. al, 1990; Brown and Peterson, 1993). Those peoples who are happy with their jobs are more likely committed to the organization .And they are expected to be satisfied from their jobs (Mowday, 1979). The employees who are more committed to their organization are more satisfied from their jobs. They consider and count themselves as the part of the organization and do as hard as they can. Sometime they watch themselves one of the main employees because of their commitment and loyalty to their job and organization. The above researches clearly tell that if employees are more committed to the organization, then they will be more happy and satisfied with their jobs. Based on this survey we assume the following hypothesis.

\section{H6: Organizational Commitment has also positive effect over job Satisfaction.}

Job Satisfaction and Turnover Intentions: According to expectancy theory, every employee expects some characteristics from their jobs. These job characteristics are job autonomy and job variety that draw them to a motivational power to perform and continue the satisfying jobs. In such jobs conditions employees will not leave their jobs and organization because their jobs and organization fulfill their favors (Vroom, 1964). In addition to this, there is also the possibility that the favorable conditions of job also meet the employee personal values. This is possible if the job gives them a sense of enjoyment and success (George and Jones, 1996).

Liking and disliking of something is a natural phenomenon. Mostly people like or dislike something for its goodness or badness. This feeling of liking or disliking behaves in the shape of attitude. Researches supports that the results of attitudes is behavioral intentions (Ajzen, 2001). Because of this as satisfaction of jobs is that attitude which comes from the workers estimate about the conditions of their jobs, which is strongly attached with turn over intentions (Spector, 1997). Attitudes sometime lead to intentions, so if some one is dissatisfied in his/her job or he/she doesn't like the environment or his/her fellow worker will most probably go for intent to leave his/her job. This well-established negative relationship between job satisfaction and turnover intentions is also shown by the literature (Mulki et al, 2006). The above researches clarify that if there is more satisfaction of job, there will be less intent to leave. We also make this our base and draw the following hypothesis.

H7: Job Satisfaction effects negatively the turn over rate. 
Structured Model: Structural Model: How Ethical Environment leads to Turnover intention is shown in Figure1.

Proposed Model

Issues and Solution of Ethical Climate and Turnover Intention in PTCL

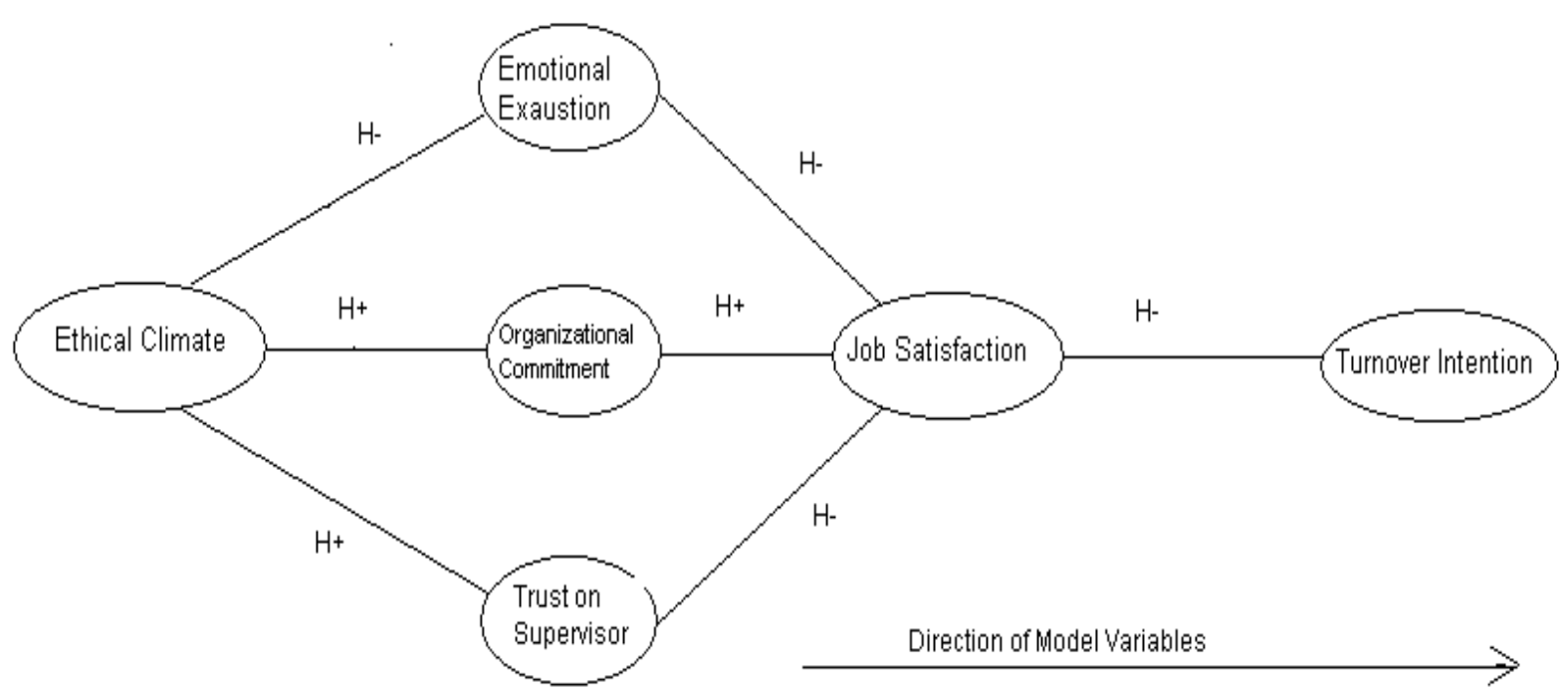

\section{Research Methodology}

Study is about the issues and solution of ethical climate and turnover intention in PTCL; we select to gather the first hand data for it. One other reason for the primary data is that there is no research regarding to this topic in Pakistan, so it is one of the primary study with a primary data. After doing the literature survey and collecting of sufficient material in the support of study, we design some of questionnaire by ourselves and some other questionnaire was included from already done researches. We made all the possible efforts to make our research more and more valuable and beneficial for its result and implementation. The following lines will explain the details of our research methodology. As in literature review, the author presented various reasons along with references from the previous researches to carry out his research. For this purpose, he had to examine the various relationships of Ethical Climate leads to Turnover Intention. The author chose the questionnaire survey method for his research from the selected samples of population.

The research was based upon Hypotheses testing, where we test the nature of certain relationships and the interdependence of two or more factors in a situation. We provided a questionnaire to the employees to undertake our research either to support our assumptions or reject them. The questionnaire was divided into seven main parts based on the variables, we used in the research. For instance, we make a separated portion for Ethical Climate, Emotional Exhaustion, and Trust in Supervisor, Organizational Commitment, Job Satisfaction and Turnover Intentions. The participants were informed about their confidentiality in the initial time of research survey. We distributed and collected the questionnaire from the employees of PTCL according to the ratio we have selected for our research. Majorly we include the employees having grade 17 or having higher grades. We appreciate employees to participate in the survey, and before filling out of the questionnaire each of them were supposed to be introduced with the survey. After collecting back the 200 questionnaires handed out, 173 were considered valid and the remaining were either not properly filled or not returned to us. Therefore, the response rate we observed was $78 \%$. 
The research we have made is also expected to be more valuable due to its data collection methods. Data of this research has been collected from the employees of PTCL. The individuals from the PTCL Islamabad were selected through a simple random sampling design, that is, in such a manner that there was an equal chance of being selected for the study, irrespective of their color, domicile, language, department and education. This process ensured the accuracy and precision of the result. As it was very difficult to collect data from all of the employees, the data collection process has been divided into five different groups and collected the data through Stratified Random Sampling. Initially we decided to keep similar ratio of collecting data for each group but it was too hard to achieve due to time, cost and some other human resources problems. The five distinct group formed contains the following groups.

- Employees having lower grade than 17

- Employees having grade 17

- Employees having grade 18

- Employees having grade19

- Employees having higher grade than 19

There were total forty questions and six variables in the questionnaires. All of the employees groups and genders were supposed to be asked the same questionnaires. After the questionnaire has been finalized, it were distributed among the employees of the selected organization and collected. It was found that the questionnaires are fit and suitable for using in the research process. The data, which was collected in this stage, was excluded from the result; it was just used for time being. The participants of our research were randomly selected form PTCL, Islamabad, Pakistan. All those members who have been chosen for the questionnaire were considered for the filling out of the questionnaire during the office hours in their offices. The questionnaire was given to the PTCL employees for completion by them in their homes and then returned to us after a weak.

\section{Results}

This chapter discusses the analysis of data of the research. For reliability and goodness of our result, we run our data through SPSS software. The following lines explain the analysis of data after applying SPSS tools.

Reliability and validity of the research: In order to make a reliable and valid research, we have tested our measures for its consistency and its stability. Consistency will show how the research variables are relating together as a set. Before distributing the questionnaires, among the employees the questionnaires were distributed and collected in PTCL. The result was checked and consider reliable and stable for further research to be done in the organization. For this purpose, we find the Cronbach's Alpha, which is a coefficient for reliability of the relationships of variables in the research. The value of this coefficient in our research is 0.848 , which is an acceptable value.

Group Statistics (Male and Female) of Issues and Solution of Ethical Climate and Turnover Intentions in PTCL: The following table describes the statistic among the gender groups (male and female). For our first variable Ethical Climate, there are 3.334 values for t-statistics having a P-value of 0.001 , which is significant. It means that male and female have different response about Ethical Climate. The t-statistical values for Organizational Commitment are 0.378 that is insignificant with the value of 0.706 . Similarly, Trust on Supervisor is significant with the statistical values of 2.085 and P-values of 0.039. Emotional Exhaustion is insignificant with the t-statistical values 0.820 and P-values 0.414. Job Satisfaction is also insignificant for the t-statistical value 0.396 and P-value 0.692 . Turnover Intention is not significant like Ethical Climate having the t-statistical values 2.465 and P-vales 0.015 . In summary males and females are not agree about Ethical Climate, Trust on Supervisor and Turnover Intention but they have same response about the remaining variables like Organizational Commitment, Emotional Exhaustion, and Job Satisfaction. 
Table 1: Group Statistics (Male and Female)

\begin{tabular}{|c|c|c|c|c|c|c|}
\hline Variables & Gender & $\mathbf{N}$ & Mean & Std. Deviation & T-statistics & P-value \\
\hline \multirow{2}{*}{ EC } & Male & 133 & 3.2202 & .82432 & \multirow{2}{*}{3.334} & \multirow{2}{*}{.001} \\
\hline & Female & 40 & 3.6750 & .45749 & & \\
\hline \multirow{2}{*}{$\mathrm{OC}$} & Male & 133 & 3.4678 & .52260 & \multirow{2}{*}{0.378} & \multirow{2}{*}{.706} \\
\hline & Female & 40 & 3.5028 & .47873 & & \\
\hline \multirow{2}{*}{ TS } & Male & 133 & 3.2531 & .87271 & \multirow{2}{*}{2.085} & \multirow{2}{*}{.039} \\
\hline & Female & 40 & 3.5625 & .62439 & & \\
\hline \multirow{2}{*}{ EE } & Male & 133 & 3.0767 & .64325 & \multirow{2}{*}{0.820} & \multirow{2}{*}{.414} \\
\hline & Female & 40 & 3.1750 & .73476 & & \\
\hline \multirow{2}{*}{ JS } & Male & 133 & 3.3759 & .64212 & \multirow{2}{*}{.396} & \multirow{2}{*}{.692} \\
\hline & Female & 40 & 3.4208 & .57733 & & \\
\hline \multirow{2}{*}{ TI } & Male & 133 & 2.8822 & 1.17901 & \multirow{2}{*}{2.465} & \multirow{2}{*}{.015} \\
\hline & Female & 40 & 3.3667 & .70932 & & \\
\hline
\end{tabular}

ANOVA Group Statistics (Positions Grade wise) of Issues and Solution of Ethical Climate and Turnover Intentions in PTCL: The following table represents the group statistics of the research among the different samples based on their positions or grades. Ethical Climate is significant among groups, having a significant value of 0.000 with F-value of 9.604. Similarly, Organizational Commitment is also significant which has the Fvalue 6.925, and 0.000 significant values. The F-value of Trust on Supervisor is 2.724 and is significant with the values .031. Emotional Exhaustion also repeats like other variables and has F-value 3.362 and significant value 0.011 . Job Satisfaction is insignificant with the F-value 0.783 and significant value 0.538 . Turnover Intention is also significant with the F-value 5.748 and significant value 0.000 . It means that there is a big variance among the different level about the research.

Table No 2: Group Statistics (Grade wise) ANOVA Test

\begin{tabular}{lllllll}
\hline \multirow{2}{*}{ Variables } & & Sum of Squares & Df & $\begin{array}{c}\text { Mean } \\
\text { Square }\end{array}$ & F & Sig. \\
\hline \multirow{2}{*}{ EC } & Between Groups & 19.396 & 4 & 4.849 & & \\
& Within Groups & 84.822 & 168 & .505 & 9.604 & .000 \\
& Total & 104.218 & 172 & & & \\
OC & Between Groups & 6.373 & 4 & 1.593 & & .000 \\
& Within Groups & 38.653 & 168 & .230 & 6.925 & \\
& Total & 45.026 & 172 & & & \\
TS & Between Groups & 7.228 & 4 & 1.807 & & \\
& Within Groups & 111.453 & 168 & .663 & 2.724 & \\
& Total & 118.681 & 172 & & & \\
EE & Between Groups & 5.631 & 4 & 1.408 & & \\
& Within Groups & 70.339 & 168 & .419 & 3.362 & .538 \\
& Total & 75.970 & 172 & & & \\
JS & Between Groups & 1.235 & 4 & .309 & & \\
& Within Groups & 66.251 & 168 & .394 & .783 & \\
& Total & 67.487 & 172 & & & \\
& Between Groups & 25.321 & 4 & 6.330 & & \\
& Within Groups & 185.007 & 168 & 1.101 & 5.748 & \\
& Total & 210.328 & 172 & & & \\
\hline
\end{tabular}


Correlation Analysis among the various variable and factors of the Issues and Solution of Ethical Climate and Turnover Intentions in PTCL: The following table shows the Correlation Matrix among the variables of our research at 0.05 and 0.01 levels of significance. This correlation matrix is drawn to check the correlation among the different variable, which have been discussed in the formulation of hypothesis. The correlation analysis results are explained in reference to the different drawn hypothesis of our research.

\section{H1: Ethical Environment affects Trust in Supervisor positively}

The following table of correlation analysis illustrate that there is positive significant relationship between Ethical Environment and Trust on Supervisor $\left(.547\left(^{* *}\right), p=0.000\right)$. This relationship was previously supported by researches (Mulki et al, 2006). Similarly, another research has also the same results (Strutton, 1993). It shows that the Ethical Climate of the firm gives both the employees positive attitudes about each other. This relation also satisfies our assumption. The value to effects trust on Supervisor is $54 \%$.

\section{H2: Ethical Climate has positive relationship with Organizational Commitment}

According to the following correlation Matrix, there is positive significant relation between Ethical Environment and Organizational Commitment. (485(**), $\mathrm{p}=.000$ ). The same relationship is previously supported by (Sims and Kroeck, 1994). It explains that when there is the environment of an organization is ethical and behave well with its employees, the employees of this organization will be committed to the organization. The value between to affect Organizational Commitment 48\%.

\section{H3: Ethical Climate has negative relationship with Emotional Exhaustion}

The correlation matrix also indicates positive significant relation of Ethical Climate and Emotional Exhaustion $\left(0.203\left(^{* *}\right), p=.027\right)$. It means that Ethical Climate will increase Emotional Exhaustion in the organization. This relation does not support our study. The value of the positivity is $20 \%$.

\section{H4: Emotional Exhaustion has negative relation ship with Job Satisfaction}

There is a positive insignificant relation between Emotional Exhaustion and Job Satisfaction shown by the following correlation matrix $(0.133,0.81)$. The relation is positive but insignificant with the value of $13 \%$ as illustrated in the given correlation table. In other words, there is no correlation between the variables.

\section{H5: Trust in Supervisor has also positive effect over Job Satisfaction}

The correlation matrix also shows that there are positive significant relation between Trust on Supervisor and Job Satisfaction $\left(.557\left(^{* *}\right), \mathrm{p}=0.000\right)$. The relation among these variable is $55 \%$ as given in the below correlation matrix.

\section{H6: Organizational Commitment has also positive effect over job Satisfaction}

The correlation table also illustrate positive significant relation between Organizational Commitment and Job Satisfaction $\left(.450\left(^{* *}\right), \mathrm{p}=0.021\right)$. The relation between the two variables is $45 \%$ as shown in the below table.

\section{H7: Job Satisfaction effects negatively the turn over rate}

There is significant negative relation between Job Satisfaction and Turnover Intention $(-.62(* *), p=0.035)$. It means that job Satisfaction will decrease the turnover of the employees in the organization. The relation between the variables is $62 \%$ as shown in the following correlation matrix. 
Table 3: Correlation Analysis among the various variable and factors of the Issues and Solution of Ethical Climate and Turnover Intentions in PTCL

\begin{tabular}{|c|c|c|c|c|c|c|c|c|}
\hline & & EC & OC & TS & EE & JS & TI & Alpha \\
\hline EC & $\begin{array}{l}\text { Pearson Correlation } \\
\text { Sig. (2-tailed) }\end{array}$ & 1 & & & & & & .856 \\
\hline $\mathrm{OC}$ & $\begin{array}{l}\text { Pearson Correlation } \\
\text { Sig. (2-tailed) }\end{array}$ & $\begin{array}{l}.547\left(^{* *}\right) \\
.000\end{array}$ & 1 & & & & & .652 \\
\hline TS & $\begin{array}{l}\text { Pearson Correlation } \\
\text { Sig. (2-tailed) }\end{array}$ & $\begin{array}{l}.485\left(^{* *}\right) \\
.000\end{array}$ & $\begin{array}{l}.566(* *) \\
.000\end{array}$ & 1 & & & & .857 \\
\hline $\mathrm{EE}$ & $\begin{array}{l}\text { Pearson Correlation } \\
\text { Sig. (2-tailed) }\end{array}$ & $\begin{array}{l}.203(* *) \\
.027\end{array}$ & $\begin{array}{l}.206(* *) \\
.007\end{array}$ & $\begin{array}{l}.266\left(^{* *}\right) \\
.000\end{array}$ & 1 & & & .690 \\
\hline JS & $\begin{array}{l}\text { Pearson Correlation } \\
\text { Sig. (2-tailed) }\end{array}$ & $\begin{array}{l}.477\left(^{* *}\right) \\
.031\end{array}$ & $\begin{array}{l}.450\left(^{* *}\right) \\
.021\end{array}$ & $\begin{array}{l}.557(* *) \\
.000\end{array}$ & $\begin{array}{l}.133 \\
.031\end{array}$ & 1 & & .750 \\
\hline TI & $\begin{array}{l}\text { Pearson Correlation } \\
\text { Sig. (2-tailed) }\end{array}$ & $\begin{array}{l}.084 \\
.274 \\
\end{array}$ & $\begin{array}{l}-.079 \\
.301 \\
\end{array}$ & $\begin{array}{l}.100 \\
.191 \\
\end{array}$ & $\begin{array}{l}.165\left(^{*}\right) \\
.030\end{array}$ & $\begin{array}{c}-.62(* *) \\
0.035\end{array}$ & 1 & .905 \\
\hline
\end{tabular}

** Correlation is significant at the 0.01 level (2-tailed)

*. Correlation is significant at the 0.05 level (2-tailed)

Regression Analysis of the Model: Regression analysis is used to find out the relationships among variables. The following summaries and its coefficients show that there is a reliable relationship between the Ethical Climate and Trust on Supervisor, Ethical Climate and Organizational Commitment, Trust on Supervisor and Job Satisfaction, Organizational Commitment and Job Satisfaction, Emotional Exhaustion and Job Satisfaction, and Job Satisfaction and Turnover Intention. The only relationship in our proposed model is between Ethical Climate and Emotional Exhaustion is not reliable. This means that we can use all the relationship for making predictions except the relation between Ethical Climate and Emotional Exhaustion.

Table 4: Ethical Climate and Emotional Exhaustion

\begin{tabular}{llllllll}
\hline & B & Std. Error & T-Stat & Sig & R-Square & F-Stat & p-value \\
\hline (Constant) & 2.490 & .267 & 9.322 & .000 & 0.031 & 3.392 & 0.068 \\
EC & .144 & .078 & 1.842 & .027 & & & \\
\hline Predi
\end{tabular}

a Predictors: (Constant), EC

b Dependent Variable: EE

In the above table, the result of regression analysis for emotional exhaustion shows that the value of R-Square is 0.0311 and the F-value is 3.392. The results reveal that the model is significant $(p<0.1)$ and there is positive weak relationship between independent and dependent variables.

Table 5: Ethical Climate and Trust on Supervisor

\begin{tabular}{llllllll}
\hline & B & Std. Error & T-Stat & Sig & R-Square & F-Stat & p-value \\
\hline (Constant) & 1.407 & .335 & 4.196 & .000 & 0.224 & 30.926 & 0.000 \\
EC & .548 & .098 & 5.561 & .000 & & & \\
\hline
\end{tabular}

a Predictors: (Constant), EC

b Dependent Variable: TS

In the above table, the result of regression analysis for trust on supervisor shows that the value of R-Square is 0.224 and the $F$-value is 30.926 . The results reveal that the model is significant $(\mathrm{p}<0.05)$ and there is positive relationship between independent and dependent variables. 
Table 6: Ethical Climate and Organizational Commitment

\begin{tabular}{llllllll}
\hline & B & Std. Error & T-Stat & Sig & R-Square & F-Stat & p-value \\
\hline (Constant) & 2.439 & .170 & 14.355 & .000 & 0.273 & 40.162 & 0.000 \\
EC & .316 & .050 & 6.337 & .000 & & & \\
\hline
\end{tabular}

a Predictors: (Constant), EC

b Dependent Variable: OC

In the above table, the result of regression analysis for organizational commitment shows that the value of $\mathrm{R}$ Square is 0.273 and the F-value is 40.162 . The results reveal that the model is significant $(p<0.05)$ and there is positive relationship between independent and dependent variables.

Table 7: Emotional Exhaustion, Trust on Supervisor, Organizational Commitment with Job Satisfaction

\begin{tabular}{llllllll}
\hline & B & Std. Error & T-Stat & Sig & R-Square & F-Stat & p-value \\
\hline (Constant) & 1.637 & .365 & 4.485 & .000 & 0.403 & 23.609 & 0.000 \\
OC & .243 & .104 & 2.346 & .021 & & & \\
TS & .329 & .055 & 5.974 & .000 & & & \\
EE & -.032 & .068 & -.474 & .031 & & & \\
\hline
\end{tabular}

a Predictors: (Constant), EE, OC, TS

b Dependent Variable: JS

In the above table, the result of regression analysis for job satisfaction predicts that the value of R-Square is 0.403 and the F-value is 23.609 . The results show that the model is significant $(p<0.05)$ and there is positive relationship between independent and dependent variables. The variables when compared on individual basis, all the variables are significant $(\mathrm{p}<.05)$. Therefore, the model is overall significant at $95 \%$ confidence level and all three independent variables are significantly important for job satisfaction, though with varying degree of importance.

Table 8: Job Satisfaction and Turnover Intentions

\begin{tabular}{llllllll}
\hline & B & Std. Error & T-Stat & Sig & R-Square & F-Stat & p-value \\
\hline (Constant) & 3.974 & .601 & 6.613 & .000 & 0.035 & 3.838 & 0.06 \\
JS & -.337 & .172 & -1.959 & .035 & & & \\
\hline
\end{tabular}

a Predictors: (Constant), JS

b Dependent Variable: TI

In the above table, the result of regression analysis for turnover intentions shows that the value of R-Square is 0.035 and the F-value is 3.838 . The results reveal that the model is significant $(p<0.1)$ and there is weak positive relationship between independent and dependent variables.

\section{Conclusion and Recommendations}

Conclusion: As the research discusses some of the important and necessary variables started from ethical Climate and ends on Turnover Intentions in PTCL. It is important to conclude that all of the variables except the relation of Emotional exhaustion and Job Satisfaction are significant and having favorable relationship which the study proposed. It is concluded from the study that there is a shortage of ethical codes and conduct in PTCL, which result low organizational commitment and lessen trust on Supervisor. It is necessary for the PTCL to introduce ethical codes for the betterment of organizational commitment and Trust on Supervisor. It is also concluded that either there is no ethical codes defined by the organization or there is no knowledge about ethical codes among the employees. Less knowledge among the employee about Ethics creates Emotional Exhaustion too, which affect the repute of the organization negatively. 
Organizational Commitment and trust on Supervisor is also very necessary for Job Satisfaction. Unfortunately, it seems that most of the employees of the organization are dissatisfied from their jobs because they are not committed to their organization due to its Ethical environment. Similarly, employees are not satisfied from their job due to their bosses or supervisors. They have no trust over them. Lastly, the employees were found that their Job Dissatisfaction leads to their Turnover, which is quite high in PTCL. Most of the employees are trying for Job somewhere else and quitting their jobs in PTCL. Most of the high-level employees of the organization are agreeing that there is very unethical environment inside the organization and having strong intentions to quit. The situation is opposite for low-grade employees, who has less job opportunities in the market and are more committed to the organization. In short, almost all of the level employees are committed with the organization but some think that Ethical conduct is very low with them.

Recommendations: It is recommended for PTCL to introduce Ethical Climate and inform each employee, from low level to high level about it.

- It is also recommended that the organization put those behaviors in action that are more employee is friendly and parallel to the ethical codes of the society in which it is operating.

- It is also suggested that PTCL should gives its employees more learning and appraising opportunities, which increase trust on Supervisor.

- Give job security to each level employee. This will increase their trust on organization and decrease the intentions of the employees to quit or search another job.

- Introduce more benefits and opportunities for high-level employees.

- Legislate that the bosses will behave with their subordinate ethically.

\section{References}

Ajzen, I. (2001). Nature and Operation of Attitudes. Annual Review of Psychology, 52(1), 27-58.

Babin, B. J., Boles, J. S. \& Robin, D. P. (2000). Representing the Perceived Ethical Work Climate among Marketing Employees. Academy of Marketing Science, 28(3), 345-358.

Babin, B. J., Griffin, M. \& Boles, J. S. (2004). Buyer Reactions to Ethical Beliefs in the Retail Environment. Journal of Business Research, 57(10), 1155-1163.

Babakus, E., Cravens-Johnston, D. W. M. \& Moncrief, W. C. (1999). The Role of Emotional Exhaustion in Sales Force Attitude and Behavior Relationships. Journal of the Academy of Marketing Science, 27(1), 5870.

Brashear, T. G., Boles, J. S., Bellenger, D. N. \& Brooks, C. M. (2003). An Empirical Test of Trust-Building Processes and Outcomes in Sales Manager-Salesperson Relationships, Academy of Marketing Science 31(2), 189-201.

Brown, S. P. \& Peterson, R. A. (1993). Antecedents and consequences of salesperson job satisfaction: metaanalysis and assessment of causal effects. J Mark Res, 30, 63-77.

Chan, M. (2002). Violations of Service Fairness and Legal Ramifications: The Case of the Managed Care Industry. Journal of Business Ethics, 36(4), 315-336.

Cordes, C. L. \& Dougherty, W. T. (1993). A Review and an Integration of Research on Job Burnout. The Academy of Management Review, 18(4), 621-656.

Deshpande, S. P. (1996). The impact of ethical climate types on facets of job satisfaction: an empirical investigation. Journal of Bus Ethics, 15(6), 55-60.

Dirks, K. T. \& Ferrin, L. D. (2002). Trust in Leadership: Meta-Analytic Findings and Implications for Research and Practice. Journal of Applied Psychology, 87(4), 611-628.

Duffy, M. K., Ganster, D. C. \& Pagon, M. (2002). Social undermining in the workplace. Academy of Management Journal, 45, 331-351.

Ethics in American business (1988). An opinion survey. New York: Touché Ross and Co.

Ferrell, O. C. \& Gresham, L. G. (1985). A contingency framework for understanding ethical decision-making. J Mark, 49, 87-96.

Ferrell, O. C. \& Skinner, S. J. (1988). Ethical behavior and bureaucratic structure in marketing research organizations. J Mark Res, 25(10), 3- 9. 
George, J. M. \& Jones, G. R. (1996). The Experience of Work and Turnover Intentions: Interactive Effects of Value Attainment, Job Satisfaction, and Positive Mood. Journal of Applied Psychology, 81, 318-325.

Gilbert, J. (2003). A Matter of Trust. Sales and Marketing Management, 155(3), 30-35.

Goodell, R. (1994). National business ethics survey findings. Ethics Journal, 1, 3-5.

Grojean, M. W., Resick, C. J., Dickson, W. M. \& Smith, D. B. (2004). Leaders, Values, and Organizational Climate: Examining Leadership Strategies for Establishing an Organizational Climate Regarding Ethics. Journal of Business Ethics, 55(3), 223-241.

Griffin, R. W. \& Lopez, Y. P. (2005). Bad behavior in organizations: A review and typology for future research. Journal of Management, 31, 988-1005.

Griffin, R. W. \& O'Leary-Kelly, A. (2004). The dark side of organizational behavior. San Francisco, CA: JosseyBass.

Hegarty, H. W. \& Sims, H. P. (1979). Organizational philosophy, policies, and objectives related to unethical decision behavior: a laboratory experiment. Journal of Applied Psychology, 64, 331- 8.

Hunt, S. D., Wood, V. R. \& Chonko, L. B. (1989). Corporate ethical values and organizational commitment in marketing. J Mark, 53, 79-90.

Jackson, S. E., Turner, J. A. \& Brief, A. P. (1987). Correlates of Burnout among Public Service Lawyers. Journal of Occupational Behavior, 8(4), 339-349.

Jaramillo, F., Mulki, J. P. \& Locander, W. B. (2006b). The Role of Time Wasted in Sales Force Attitudes and Intentions to Quit. International Journal of Bank Marketing, 21(1), 24-36.

Jaramillo, F., Mulki, J. P. \& Solomon, P. (2006a). The Role of Ethical Climate on Salesperson_s Role Stress, Job Attitudes, Turnover Intention, and Job Performance. Journal of Personal Selling \& Sales Management 26(3), 271-282.

Johnston, M. W., Parasuraman, A., Futrell, C. M. \& Black, W. C. (1990). A longitudinal assessment of the impact of selected organizational influences on sales people's organizational commitment during early employment. J Mark Res, 27, 333- 44.

Low, G. S., Cravens, D. W., Grant, K., Mitchell, W. C., Holtom, T. R. B. C., Lee, T. W., Sablynski, C. J. \& Erez. M. (2001). Why People Stay: Using Job Embeddedness to Predict Voluntary. Academy of Management Journal, 44, 1102-1121.

March, J.G. \& Simon, H. A. (1958). Organizations, Wiley, New York, NY.

Mathieu, J. E. Zajac, D. M. (1990). A review and meta-analysis of the antecedents, correlates, and consequences of organizational commitment. Psychol Bull, 108, 171 - 94.

McDonald, G. (1999). Business ethics: practical proposals for organizations. Journal of Business Ethics, 19, 143-58.

Miller, C. (2009). The Conditions of Moral Realism. The Journal of Philosophical Research, 34, 123-155.

Mowday, R. T. \& McDade, T. W. (1979). Linking behavior and attitudinal commitment: a longitudinal analysis of job choice and job attitudes. Acad Manage Proc. 84- 8.

Mulki, J. P., Jaramillo, F. \& Locander, W. B. (2006). Effects of Ethical Climate and Supervisory Trust on Salesperson_s Job Attitudes and Intentions to Quit, Journal of Personal Selling \& Sales Management 26(1), 19-26.

Neese, W. T., Ferrell, L. \& Ferrell, O. C. (2005). An Analysis of Federal Mail and Wire Fraud Cases Related to Marketing. Journal of Business Research, 58(6), 910-918.

Netemeyer, R. G., Brashear-Alejandro, T. \& Boles, J. S. (2004). A Cross-National Model of Job-Related Outcomes of Work Role and Family Role Variables: A Retail Sales Context. Journal of the Academy of Marketing Science, 32, 49-60.

Posner, B. Z. \& Schmidt, W. H. (1987). Ethics in American companies: a managerial perspective. J Bus Ethics, 6, 383- 91.

Porter, L. W., Steers, R. M., Mowday, R. T. \& Boulian, P. V. (1974). Organizational commitment, job satisfaction and turnover among psychiatric technicians. Journal of Applied Psychology, 59, 603- 9.

Rizzo, J. R., House, R. J. \& Lirtzman, S. (1970). Role Conflict and Ambiguity in Complex Organizations. Administrative Science Quarterly, 15(2), 150-63.

Robin, D. P. \& Reidenbach, E. R. (1987). Social responsibility, ethics, and marketing strategy. J Mark, 39, 20 -7.

Ruppel, C. P. \& Harrington, S. J. (2000). The Relationship of Communication, Ethical Work Climate, and Trust to Commitment and Innovation. Journal of Business Ethics, 25(4), 313-328.

Schneider, B. (1975). Organizational climate: an essay. Personal Psychology, 28(4), 47-79. 
Schneider, B. \& Rentsch, J. (1988). Managing climates and cultures: a future perspective, in futures of organizations. In: Hage J, editor. Lexington, MA: Lexington Books, 181- 200.

Schwepker, C. H. J. (2001). Ethical Climates Relationship to Job Satisfaction, Organizational Commitment and Turn over in the Sales Force. Journal of Business Research, 54(1), 39-52.

Schwepker, C. H., Ferrell, O. C. \& Ingram, T. N. (1997). The influence of ethical climate and ethical conflict on role stress in the sales force. J Acad Mark Sci, 25, 99-108.

Sims, R. L. \& Kroeck, G. K. (1994). The influence of ethical fit on employee satisfaction, commitment and turnover. J Bus Ethics, 13, 939-47.

Spector, P. E. (1985). Measurement of Human Service Staff Satisfaction: Development of the Job Satisfaction Survey. American Journal of Community Psychology, 13, 693-713.

Spector, P. E. (1997). Job Satisfaction: Application, Assessment, Causes, and Consequences (Sage, Thousand Oaks, CA).

Staw, B. M. \& Salancik, G. R. (1977). New Directions in Organizational Behavior. Academy of Management Review, 3, 17-29.

Strutton, D., Pelton, L. E. \& Lumpkin, J. R. (1993). The Relationship between Psychological Climate and Salesperson-Sales Manager Trust in Sales Organizations. Journal of Personal Selling \& Sales Management, 13(4), 1-14.

Tepper, B. J. (2000). Consequences of abusive supervision. Academy of Management Journal, 43, 178-190.

Tepper, B. J., Duffy, M. K., Henle, C. A. \& Lambert, L. S. (2006). Procedural justice, victim precipitation, and abusive supervision. Personnel Psychology, 59, 101-123.

Trevino, L. K. (1986). Ethical decision making in organizations: a person situation integrationist model. Academy Manage Review, 11, 601- 17.

Verbeke, W., Ouwerkerk, C. \& Peelen, E. (1996). Exploring the contextual and individual factors on ethical decision making of salespeople. J Bus Ethics, 15(11), 75- 87.

Victor, B. \& Cullen, J. B. (1988). The organizational bases of ethical work climate. Adm Sci Q, 33(10), 1- 25.

Vitell, S. J, Davis, D. L. (1990). The relationship between ethics and job satisfaction: an empirical investigation. J Bus Ethics, 9, 489 -94.

Vroom, V. H. (1964). Work and Motivation (Wiley).

Weeks, W. \& Nantel, J. (1992). Corporate codes of ethics and sales force behavior: A case study. J Bus Ethics, 11(7), 53-60.

Wimbush, J. C. \& Shepard, J. M. (1994). Toward an Understanding of Ethical Climate: It's Relationship to Ethical Behavior and Supervisory Influence. Journal of Business Ethics, 13(8), 637-647.

Zellars, K. L., Tepper, B. J. \& Duffy, M. K. (2002). Abusive supervision and subordinates organizational citizenship behavior. Journal of Applied Psychology, 87, 1068-1076. 